\section{Blind Landing System at Aerodromes}

IT is reported that 40 R.A.F. aerodromes are now to be equipped with blind-landing approach apparatus. This will presumably be the Jorenz system, already in use at Croydon, Heston and Manchester civil aerodromes, and extensively on the Continent, particularly in Germany. In principle, it consists of a wireless beam along and down which the machine flies as it approaches the radiating station, on or near to the aerodrome. The waves are picked up by the aircraft's apparatus, and turned into signals arranged so that they give warning to the pilot of any deviation of his from the line of approach, both in regard to his angle to the earth and in a horizontal plane. A further warning is given when it is necessary to flatten out preparatory to landing. The adoption of such a system will facilitate the operation of bomber squadrons in bad weather conditions. The presence of low cloud, mist or fog, is often an advantage to bombers when attacking, in that it helps to screen them from fighter and ground defences. It is obviously important that they should be independent of these conditions when operating from their home aerodromes. The fact that these facilities may be available in emergencies for civil aircraft, should encourage a more general adoption of the system in civil aviation, which will help to promote both safety and regularity in service in civil air transport.

\section{Early Races of the Far North in America}

Dr. Aleš HrdLIČKa, of the Smithsonian Institution, Washington, having completed his tenth summer season of archæological and ethnological investigation in high latitudes, has brought his exploration of the far north of the American continent to a close, and is now engaged in the examination of the skeletal remains of the Aleutian and preAleutian peoples, as well as of the specimens of the material culture of the latter, collected in the last three years. Dr. Hrdlička gave a summary of his results in his annual Smithsonian lecture, which was delivered in the auditorium of the New National Museum, Washington, on November 8. $\mathrm{He}$ then pointed out that when he entered upon this investi. gation ten years ago, it was supposed that only two peoples lived in this part of the globe, the Eskimo with the Aleut and the Indians. Now six races are recognized. There are two distinct types of Indians and two types of Eskimo, while it is established that the Aleut are distinct from the Eskimo. The most interesting discovery made by Dr. Hrdlička is, however, the sixth race, the pre-Aleut people, whom he regards as close to the Shoshonean and the Californian Indian. Some of them, though not all, practised mummification, and it may be that the Aleut followed them in this practice, as in a few places mummies of the two races have been found together. The remains of the older people, the preAleuts, show close affinities with the peoples who were discovered in the lowest levels of the old village site on Kodiak island; but whereas those peoples appear to have been exterminated in a great slaughter, the pre-Aleuts appear to have escaped this fate, although as a distinct people they have disappeared. The evidence which has been gathered points to the pre-Aleuts having reached these islands from Alaska, whither their ancestors had migrated at a very much earlier date from Asia. Dr. Hrdlička dates their coming to the Aleutians at approximately two thousand years ago.

\section{Recent Accessions to the British Museum}

Among recent additions to the ethnographical collections of the British Museum (Bloomsbury) announced at the November meeting of the Trustees, were four loans by the King from the Royal collections. Of these, one is a war drum carved from the trunk of a tree, with human skull attached, taken from the King of Ashanti at his defeat in 1826 and presented to George IV; and a Maori chief's staff of office, a combined spear and club, which was presented to Queen Victoria by Maori chiefs in 1884. The National Art Collections Fund has purchased for the Museum a gold Persian wine-bowl of the eleventh or twelfth century, having a Kufic inscription around the rim in praise of wine, and an ormamental design in which several realistic representations of ducks are a prominent feature. Among other gifts are a collection of antiquities, including small bowls, dishes and scarabs of the Eighteenth Dynasty (c. 1370 B.c.) from the excavations of the Egypt Exploration Society at Sesebi in the Sudan, given by that Society; a small finely carved Egyptian lion of ivory, probably dating from the First Dynasty about 3300 B.o., given by Mr. and Mrs. Alec Rea; and a bronze head of a Pharaoh, probably Ptolemaic, given by Lord Harlech; while Mr. Reay Geddes has deposited on loan an Indian sculpture in stone of the eleventh or twelfth century, which represents Agni, the god of fire, surrounded by worshippers and goat-headed attendants. Mr. Alvan T. Marston, with the consent of the Portland Cement Manufacturers, Ltd., has presented to the Trustees the Swanscombe skull and the bones and implements associated with it. The skull and some of the implements have been allotted for exhibition at the British Museum (Natural History), while the remainder are to be exhibited in the archæological collections at Bloomsbury. These implements have been pronounced to be Early Middle Acheulean, Breuil's Acheulean III.

\section{Portrayal of Weather in Art}

THE Quarterly Journal of the Royal Meteorological Society for October contains a valuable paper by Mr. L. C. W. Bonacina on "Turner's Portrayal of the Weather". Landscape features and weather are the warp and weft of scenery, and the proper understanding of Turner's work as portrayer of scenery has been greatly hindered by the fact that such artists are described as landscape painters, and further by the circumstance that the salability of their work depends largely upon giving the picture a local name. Turner's pictures may be divided into two classes, those in which the motif is provided by the features of the landscape proper and those in which the motif is provided by the aspect of the weather; and the latter are probably the more important part of 
Turner's contribution to nature study. Mr. Bonacina's detailed discussion of notable examples of Turner's pictures in the National Gallery, the Tate Gallery, and the Victoria and Albert Museum deserves the careful consideration of students of both science and art. The attention of these specialists and also of persons of general culture may properly be directed to the following sentence in which the outlook of the author is strikingly expressed: "the co-ordination and unification of truth acquired on the one hand through scientific research and on the other expressed through artistic intuition are the intellectual needs of the age".

\section{Recent Work in Meteorology}

THE annual report of the Director of the Meteorological Office for the year ended March 31, 1938, describes the work of a period during which attention has been focused on the ever-growing needs of the rapidly expanding Royal Air Force and civil aviation. Many new meteorological stations were opened during that period on service and civil aerodromes as trained staff became available. The installation of direct teleprinter connexions between the meteorologieal stations in the country and the Air Ministry Meteorological Office headquarters was begun and arrangements for its extension to the constantly growing network of similar stations had to be considered. Meteorological information for the trans-Atlantic flights of July 1937 was supplied from stations set up at the Shannon Airport and at Botwood. The first of these was worked on an agency basis by the Meteorological Office for the Government of Eire, and the second was operated by the Canadian Meteorological Service on behalf of the Government of Newfoundland. Conferences were held afterwards at Toronto and Dublin to review the meteorological organization and improve it.

ON the research side, important work was done in collaboration with the National Physical Laboratory in developing apparatus for measuring upper air conditions by radio instruments carried on unmanned balloons, so as to obtain immediate information about wind, pressure and temperature up to greater heights than could be reached when observations were made in aeroplanes. An additional advantage from the new methods is that the information can be obtained in weather dangerous for flying. Climatic conditions in Africa during years when there were serious outbreaks of locust swarms were under investigation on behalf of the Committee on Locust Control.

\section{Electric Heating for Merchant Ships}

THE heating installation of a merchant ship is very different from that of a building on shore. An ocean. going merchant ship may sail into cold weather at any time of the year. In the course of a week she may sail from tropical heat into almost arctic conditions ; and in a voyage of a month's duration she may sail from winter in one hemisphere, through spring, summer and autumn, or vice versa, and come into winter conditions in the other hemisphere. A paper on this subject was read to the Institution of
Electrical Engineers on November 24 by $H$. C. Macewan. A difficulty of arriving at a simple method of calculation, like that used for computing the electric heating for a building, arises from the fact that the regulations quoted in specifications are very vague. Recently the British Board of Trade stated in its instructions to its surveyors in relation to master's and crew's spaces that "a heating system will be considered satisfactory if it is capable of maintaining a temperature of $60^{\circ} \mathrm{F}$., when the tem. perature of the outside air is $30^{\circ} \mathrm{F}$." This, although a useful help for making calculations, is insufficient as the basis for a test to show the adequacy of the heating. Mr. Macewan has collected data for the calculation of quantities and gives a general review of the problem as it exists to-day. He points out that the capital cost of the electric heating of ships is usually less than that of other systems as it is cheaper to run electric cables than pipes. In running cost also, electric heating is cheap, as it usually acts as a 'demand leveller' and it is seldom necessary to run an extra generator.

\section{Broadcasting in India}

Is Electrotechnics, the journal of the Electrical Engineering Society of the Indian Institute of Science, Bangalore, of April, we learn that the Government of India is making progress with the construction of broadcasting stations. In December 1937, the 5-kw. medium-wave transmitter at Lahore and the 10-kw. short-wave station at Delhi commenced operation. The short-wave station at Bombay-also of $10 \mathrm{kw}$. - started to radiate early in February, and Lucknow early in April. The 0.25-kw. medium-wave and the 10-kw. short-wave transmitters at Madras were put into regular service from the middle of June. The Trichinopoly 5-kw. medium-wave station is expected to commence operation at an early date. Several Provincial Governments have already distributed a small number of receivers for group listening in villages. The broadcasting authorities of the Central Government have under way a programme for installing 120 receivers in as many villages in the Delhi Province. At the present moment, the broadcasting service touches but a fringe of the population and the programmes are of limited appeal. The element of novelty and wonder is still the dominating factor in reception amongst all classes of listeners. Listening for pure entertainment and enjoyment, oblivious to the mechanism, is as yet virtually non-existent in India. Until the present uncritical listening gives place to the habit of tuming to radio for enjoyment, such questions as the acoustical requirements of studios and the special requirements demanded by Indian music and its technique can receive no adequate and satisfactory answer. In this journal, Mr. K. Sreenivasan's thoughtful address on the design of studios for broadcasting is published.

\section{Oxford Science}

THE first number of a new shilling quarterly called Oxford Science, edited and published by the Junior scientific Club, and printed at the Oxford University 